\title{
A Facile Approach to the Synthesis of n-Type $\pi$-Conjugated Hyperbranched Polymers
}

\author{
Takashi Koga ${ }^{1}$, Yuta Nabae ${ }^{1 *}$, Akiyasu Funakawa ${ }^{2}$, \\ Teruaki Hayakawa ${ }^{1}$, and Masa-aki Kakimoto ${ }^{1}$ \\ ${ }^{1}$ Department of Materials Science and Engineering, Tokyo Institute of Technology, \\ 2-12-1 S8-26, Ookayama, Meguro-ku, Tokyo 152-8552, Japan \\ ${ }^{2}$ Technical Department of Electrolysis Systems, Ion Exchange Membranes Division, \\ Performance Materials SBU, Asahi Kasei Corporation, \\ 7-4319, Asahi, Nobeoka, Miyazaki 882-0847, Japan \\ *nabae.y.aa@m.titech.ac.jp
}

\begin{abstract}
A facile approach for the synthesis of an n-type $\pi$-conjugated hyperbranched polymer, namely hyperbranched polypyridinebenzene, is proposed based on the copolymerization of 1,3,5-tribromobenzene $\left(\mathrm{BeBr}_{3}\right)$ and 2,5-dibromopyridine via chain-growth condensation polymerization catalyzed by $\mathrm{Ni}(\mathrm{dppp}) \mathrm{Cl}_{2}$. The use of $\mathrm{BeBr}_{3}$ as a branching unit simplifies the synthesis of $n$-type $\pi$-conjugated hyperbranched polymers, compared with a similar hyperbranched polymer prepared from 2,4,6-tribromopyridine $\left(\mathrm{PyBr}_{3}\right)$ and 2,5dibromopyridine requiring a lengthy synthetic route to give the starting material $\mathrm{PyBr}_{3}$. The results of UV-Vis spectroscopy and cyclic voltammetry suggest that our synthesized polymer retains its hyperbranched structure, which is beneficial in electrochemical doping.
\end{abstract}

Keywords: Polypyridine, Cross-coupling, Chain-growth condensation, Doping

\section{Introduction}

Conjugated polymers based on polythiophene are lightweight and flexible, and tend to exhibit good processability and optoelectronic characteristics $[1,2]$. While many $\mathrm{p}$-type and n-type conjugated polymers have been examined for application in a wide range of organic optoelectronic devices, such as solar cells $[3,4]$, light emitting diodes $[5,6]$ and transistors $[7,8]$, the development of novel conjugated polymers is necessary to expand the applicability of such materials [9-14].

Hyperbranched polymers (HBPs) are highly branched dendritic macromolecules that can be synthesized via a one-step polymerization procedure, and exhibit unique properties, such as good solubilities, low viscosities, and numerous terminal functional groups compared to linear polymers [15-17]. Although the introduction of hyperbranched structures into aromatic polymers such as polyamides $[18,19]$, polyimides [20,21], poly(ether sulfone)s [22-24], and poly(ether ketone)s [25-27], has been relatively well explored along with their applications as functional materials
[28-36], similar studies focusing on conjugated polymers are limited $[37,38]$.

The first report into p-type conjugated hyperbranched polymers was published by $\mathrm{Xu}$ and $\mathrm{Pu}$ in 2002, where they reported a hyperbranched polythiophene for use as a light-harvesting material for photovoltaic and light-emitting devices [39]. Richter et al. later expanded the concept of p-type conjugated hyperbranched polymers by reporting an alternative hyperbranched polythiophene with improved solubility imparted by its hyperbranched structure [40].

In contrast, n-type conjugated hyperbranched polymers had previously received little attention. However, in 2017, our group reported the synthesis of a hyperbranched polypyridine (HBPPy) as the first example of an n-type conjugated hyperbranched polymer [41]. This polymer was prepared by the copolymerization of 2,4,6tribromopyridine $\left(\mathrm{PyBr}_{3}\right)$ and 2,5-dibromopyridine $\left(\mathrm{PyBr}_{2}\right)$ via chain-growth condensation polymerization catalyzed by $\mathrm{Ni}(\mathrm{dppp}) \mathrm{Cl}_{2}$. Compared to its linear analogue, polypyridine 
(LPPy), HBPPy exhibited a quick response during electrochemical doping due to the enhanced diffusion of dopant cations caused by the hyperbranched structure. However, the synthesis of HBPPy is both time consuming and relatively energy intensive, mainly due to the preparation of the $\mathrm{PyBr}_{3}$ monomer. Thus, if this branching unit could be replaced by a more widely available compound, the application of n-type conjugated hyperbranched polymers could potentially be further expanded.

In this context, we propose the synthesis of an ntype conjugated hyperbranched polymer, namely hyperbranched polypyridinebenzene (HBPPyBe), by the copolymerization of 1,3,5-tribromobenzene $\left(\mathrm{BeBr}_{3}\right)$ and $\mathrm{PyBr}_{2}$, as outlined in Scheme 1. Indeed, $\mathrm{BeBr}_{3}$ is a widely available chemical, and so its use will simplify the synthesis of n-type conjugated hyperbranched polymers if the reactivity in the polymerization stage and the properties of the resulting polymer are similar to those of $\mathrm{PyBr}_{3}-$ based structures. The advantages of applying hyperbranched structures in electrochemical doping is also examined using cyclic voltammetry.

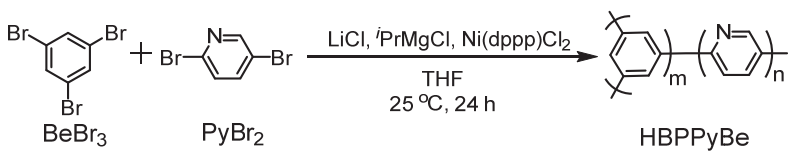

Scheme 1. Synthesis of HBPPyBe.

\section{Experimental}

\subsection{Synthesis}

Lithium chloride (Kanto Inc.) and [1,3bis(diphenylphosphino)propane] nickel(II) chloride (Ni(dppp) $\mathrm{Cl}_{2}$, Sigma-Aldrich) were dried by heating under vacuum for $1 \mathrm{~h}$. $\mathrm{PyBr}_{2}$ (TCI), $\mathrm{BeBr}_{3}$ (TCI), and tetrahydrofuran (THF, stabilizer-free, Kanto Inc.) were used as received.

In a two-necked flask, $\mathrm{LiCl}(0.67 \mathrm{~g}, 16 \mathrm{mmol}$, 16.8 eq.) and $\mathrm{PyBr}_{2}(0.90 \mathrm{~g}, 3.8 \mathrm{mmol}, 4$ eq.) were heated under $\mathrm{N}_{2}$ to remove all traces of water. Dry THF $(80 \mathrm{~mL})$ was then added followed by the slow addition of a solution of isopropylmagnesium chloride in THF (2.0 M, $1.9 \mathrm{~mL}, 3.8 \mathrm{mmol}, 4$ eq. $)$ at $0{ }^{\circ} \mathrm{C}$. The resulting mixture was then stirred at $0{ }^{\circ} \mathrm{C}$ for $2 \mathrm{~h}$. In another flask, a solution of $\mathrm{LiCl}(0.17 \mathrm{~g}$, $4.0 \mathrm{mmol}, 4.2$ eq.) and $\mathrm{BeBr}_{3}(0.30 \mathrm{~g}, 0.95 \mathrm{mmol}$, 1 eq.) in dry THF $(20 \mathrm{~mL})$ was mixed with a solution of isopropylmagnesium chloride in THF (2.0 M, $0.47 \mathrm{~mL}, 0.95 \mathrm{mmol}, 1$ eq.) as above, and the mixture was transferred to the $\mathrm{PyBr}_{2}$-containing flask using a syringe. In addition, a suspension of $\mathrm{Ni}(\mathrm{dppp}) \mathrm{Cl}_{2}(40 \mathrm{mg}, 74 \mu \mathrm{mol})$ was prepared in dry
THF (24 mL) under $\mathrm{N}_{2}$, and the suspension was added to the monomer mixture prior to stirring for $24 \mathrm{~h}$ at $25{ }^{\circ} \mathrm{C}$. After this time, the reaction was quenched using a $5 \mathrm{M}$ solution of $\mathrm{HCl}$, and the residue obtained following concentration of this mixture was dissolved in formic acid $(20 \mathrm{~mL})$ prior to precipitation with methanol $(\times 2)$. The resulting powder was dried under vacuum to obtain HBPPyBe as an ocher solid (0.228 g, 58\%).

HBPPyBe-14 (0.164 g, 37\%) and HBPPyBe-33 $(0.167 \mathrm{~g}, 43 \%)$ were prepared according to the above procedure but with different $\mathrm{BeBr}_{3} / \mathrm{PyBr}_{2}$ ratios, as outlined in Table 1.

Table 1. Polymerization conditions and polymer properties.

\begin{tabular}{cccc} 
Polymer & $\mathrm{BeBr}_{3} / \mathrm{PyBr}_{2}$ & MALDI $^{\mathrm{a}}$ & Solubility $^{\mathrm{b}}$ \\
\hline HBPPyBe-14 & $1 / 6$ & $1000-4300$ & FA, SA \\
HBPPyBe-20 & $1 / 4$ & $1200-4900$ & FA, SA \\
HBPPyBe-33 & $1 / 2$ & - & none
\end{tabular}

${ }^{a} \mathrm{DCTB}$ and $\mathrm{CF}_{3} \mathrm{COONa}$ were used as the matrix and the salt, respectively. ${ }^{\mathrm{b}}$ The solubility was determined by dissolving $1 \mathrm{mg}$ polymer in $1 \mathrm{~mL}$ solvent. FA: formic acid, SA: conc. sulfuric acid.

\subsection{Measurements}

Fourier transform infrared (FT-IR) spectra of the polymers were obtained using a JASCO FT/IR 4100 spectrometer equipped with a diamond ATR crystal. Ultraviolet-visible (UV-Vis) absorption spectra were recorded using a BAS SEC2000 spectrometer. Elemental analysis was conducted using a J-science Micro Corder JM10. Matrix assisted laser desorption ionization-time of flight mass spectrometry (MALDI-TOF MS) was carried out using a Shimadzu MALDI-TOF-MS AXIMA Performance instrument with a mixture containing a 2-[(2E)-3-(4-tert-butylphenyl)-2-methylprop-2enylidene]malononitrile (DCTB) matrix and $\mathrm{CF}_{3} \mathrm{COONa}$.

\subsection{Electrochemical study}

Cyclic voltammetry (CV) was conducted in the same manner as in our previous study [41], using a single-compartment three-electrode cell at room temperature. The working electrode was fabricated on a glassy carbon substrate or an indium tin oxide (ITO) substrate by drop-casting. A polymer loading of $19 \mu \mathrm{g} \mathrm{cm}^{-1}$ was employed. $\mathrm{Ag} / \mathrm{AgNO}_{3}$ and $\mathrm{Pt}$ wire electrodes were used as the reference and counter electrodes, respectively. A $\mathrm{CH}_{3} \mathrm{CN}$ electrolyte containing $0.1 \mathrm{M}$ tetrabutylammonium 
tetrafluoroborate was used throughout. Cyclic voltammograms were recorded by sweeping the potential between 0 and $-2.3 \mathrm{~V}$ at a scan rate of $50 \mathrm{mV} \mathrm{s}^{-1}$ using a Hokuto Denko HSV 100 potentiostat.

\subsection{Oligomer DFT calculations}

Density functional theory (DFT) calculations were performed using the B3LYP hybrid functional in Gaussian 09 [42]. Energy levels and the frequency of the pyridine oligomers were calculated using the $6-311++\mathrm{G}(\mathrm{d}, \mathrm{p})$ basis set. The bromine atoms at the ends of the oligomers were replaced with hydrogen to reduce the computational load.

\section{Results and discussion}

HBPPyBe was synthesized by the catalysttransfer polycondensation of $\mathrm{BeBr}_{3}$ and $\mathrm{PyBr}_{2}$ using a range of monomeric ratios, as outlined in Table 1. We found that the polymers prepared using relatively small amounts of $\mathrm{BeBr}_{3}$, i.e., HBPyBe-14 and -20 , were soluble in formic acid and concentrated sulfuric acid, whereas HBPPyBe-33 was insoluble in all solvents. The results of the MALDI-TOF MS analysis are summarized in Table 1 and Fig. 1. Although the predicted molecular weight based on the polymerization conditions (i.e., $1.5 \mathrm{~mol} \%$ of $\mathrm{Ni}$ catalyst) was 6000 , the mass spectrum of HBPPyBe indicated mass numbers in the range of $1000-4900$, and all peak intervals corresponded approximately to the weight of the repeating unit, thereby suggesting the successful polymerization of HBPPyBe. It should be noted that the MS signals of the LPPy polymer appeared at a lower range, i.e., 1000-1500, likely due to poor solubility at the polymerization stage [41]. In general, the HBPPyBe polymers were insoluble in

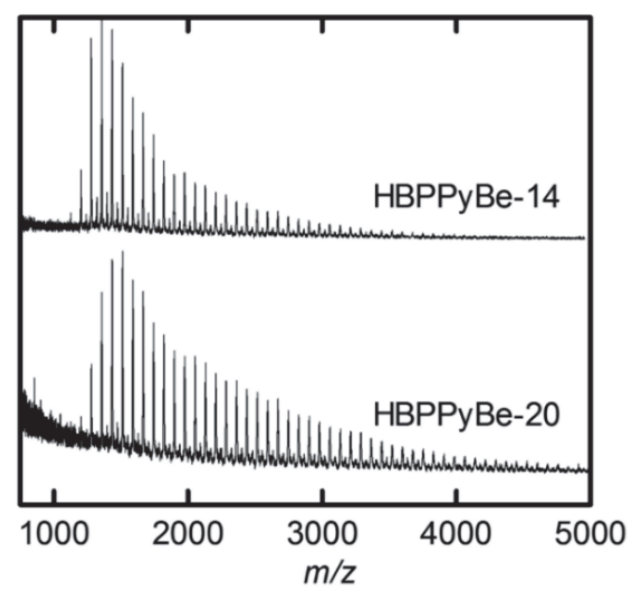

Fig. 1. MALDI-TOF MS spectra of HBPPyBe. typical organic solvents but were soluble in formic acid and concentrated sulfuric acid. The poor solubility of HBPPyBe-33 was considered to be due to the introduction of cross-linking networks by the branching units or due to the poor basicity caused by the lower pyridine fraction in this species. Furthermore, the polymer molecular weight increased upon increasing the $\mathrm{BeBr}_{3} / \mathrm{PyBr}_{2}$ ratio, likely due to the improvement in solubility resulting from the hyperbranched structure.
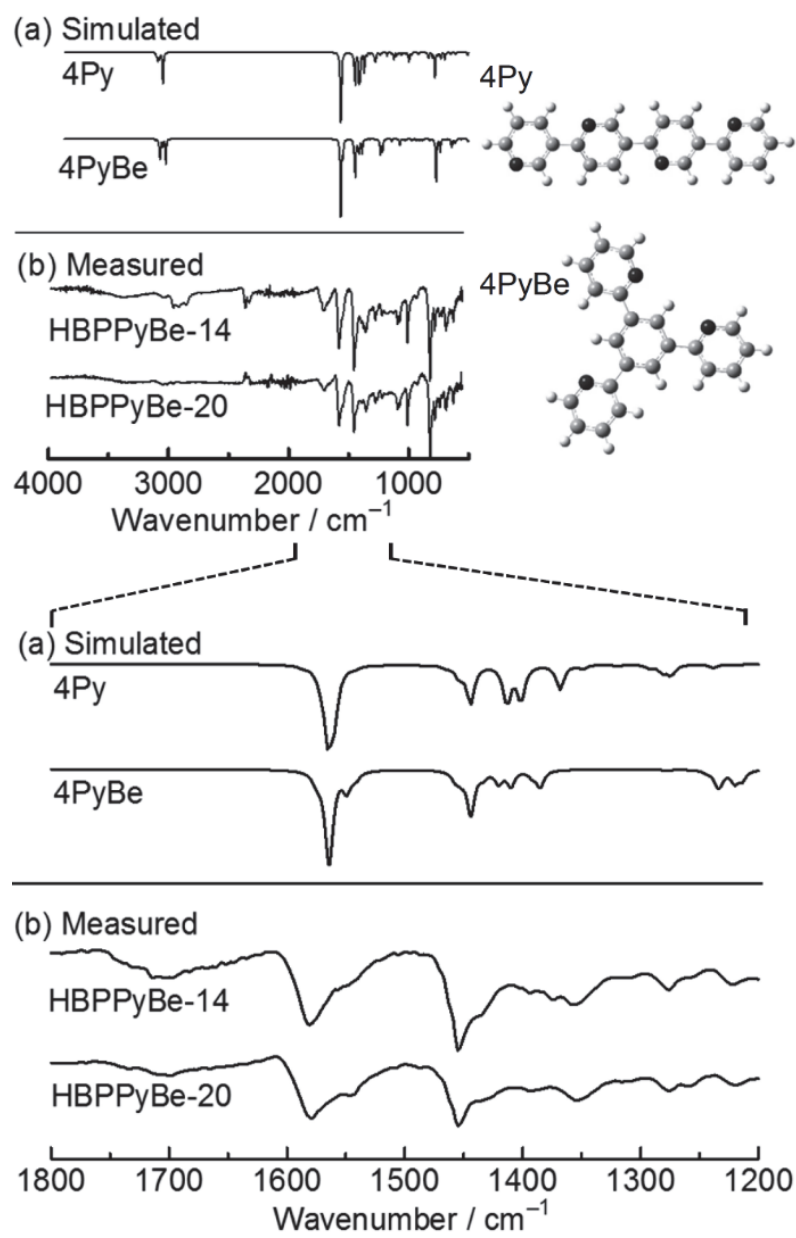

Fig. 2. (a) Simulated (B3LYP/6-311++G(d,p)) and (b) measured FT-IR spectra of the pyridine oligomer and the synthesized polymer, respectively.

Table 2. Elemental analysis of HBPPyBe.

\begin{tabular}{ccccc}
\hline Polymer & $\mathrm{C} / \%$ & $\mathrm{H} / \%$ & $\mathrm{~N} / \%$ & $\begin{array}{c}\text { Trifunctional } \\
\text { unit content }\end{array}$ \\
\hline HBPPyBe-14 & 64.4 & 1.42 & 10.7 & 0.25 \\
HBPPyBe-20 & 62.1 & 1.16 & 9.56 & 0.30 \\
HBPPyBe-33 & 57.6 & 0.95 & 7.27 & 0.41 \\
\hline
\end{tabular}


The detailed structures of the synthesized polymers were then determined by elemental analysis and FT-IR. As indicated in Table 2, the decrease in the nitrogen content upon increasing the $\mathrm{BeBr}_{3} / \mathrm{PyBr}_{2}$ ratio is expected, as $\mathrm{BeBr}_{3}$ does not contain nitrogen. In addition, Fig. 2 shows the FTIR spectra of HBPPyBe and the simulated spectrum for the branching unit. The simulated spectrum for the linear unit was reproduced from our previous study for comparison [41]. In the measured spectra, the absorbance at $1540 \mathrm{~cm}^{-1}$ increased with the $\mathrm{BeBr} 3 / \mathrm{PyBr}_{2}$ ratio. This absorbance is likely derived from the branching unit, as the difference was reproduced in the simulated spectra. These results clearly indicate that the branching unit was successfully introduced into the synthesized polymers through the cross-coupling approach.

The effect of the branching unit on the molecular orbitals was then examined based on the DFT calculation results. Figure 3 shows the structure of the molecular orbitals around the highest occupied molecular orbital (HOMO) and the lowest unoccupied molecular orbital (LUMO) of the model molecules for the linear and branched systems, 6Py and $7 \mathrm{PyBe}$, respectively. Compared to the linear system, the molecular orbitals of the branched systems do not appear to be evenly hybridized. This is also reflected in the simulated UV-Vis spectra and the oscillator strength, as indicated in Fig. 4, Table 3 , and Table 4. In addition, the UV-Vis adsorption of $7 \mathrm{PyBe}$ was scattered and was predicted to take place at lower wavelengths, while that of $6 \mathrm{Py}$ exhibited a peak at $382 \mathrm{~nm}$ corresponding to a single excited state. It therefore appeared that the simulation predicted a shortened and more complicated $\pi$-conjugated system for the hyperbranched polypyridine structure.

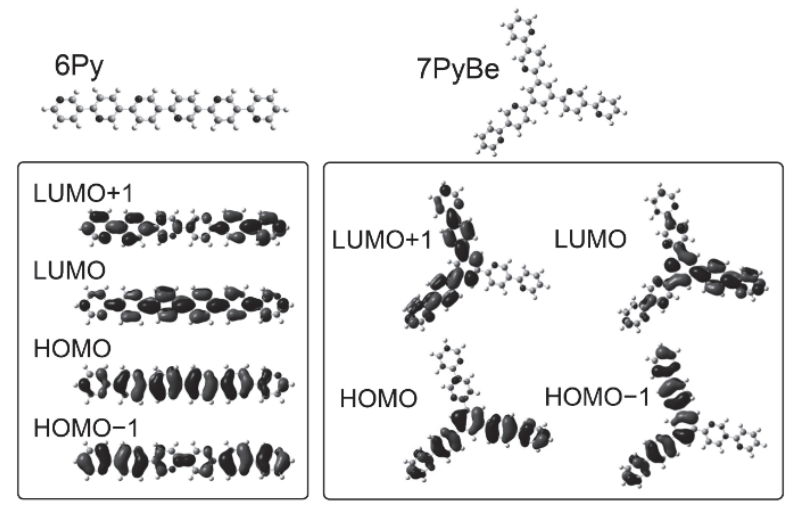

Fig. 3. Topologies of the pyridine oligomer molecular orbitals calculated using the B3LYP/6-311++G(d,p) basis set.
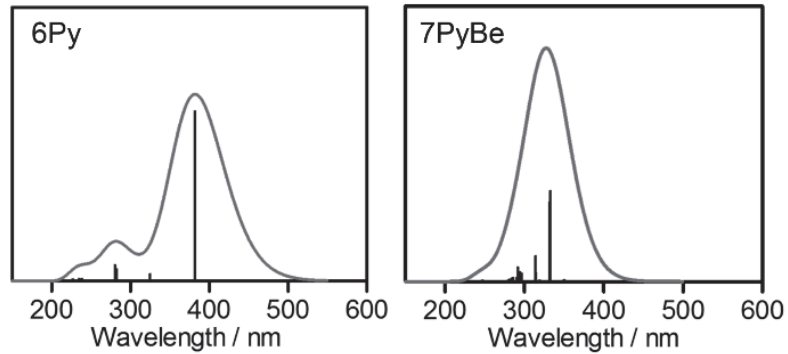

Fig. 4. Simulated absorption spectra of 6Py and 7PyBe with the oscillator strengths shown as vertical bars (calculated using the B3LYP/6-311++G(d,p) basis set).

Table 3. Excited states and oscillator strengths of 6Py calculated using the B3LYP/6-311++G(d,p) basis set.

\begin{tabular}{|c|c|c|c|c|}
\hline & \multicolumn{2}{|c|}{ Excited state } & $\Delta E / \mathrm{eV}, \mathrm{nm}$ & $f$ \\
\hline $\begin{array}{c}\text { Excited } \\
\text { state 1 }\end{array}$ & HOMO & $>$ LUMO & $3.24,382$ & 2.18 \\
\hline $\begin{array}{l}\text { Excited } \\
\text { state } 2\end{array}$ & $\begin{array}{c}\text { HOMO-1 } \\
\text { HOMO }\end{array}$ & $\begin{array}{ll}> & \text { LUMO } \\
> & \text { LUMO+1 }\end{array}$ & $3.82,324$ & 0.10 \\
\hline $\begin{array}{l}\text { Excited } \\
\text { state } 3\end{array}$ & $\begin{array}{c}\text { HOMO-1 } \\
\text { HOMO }\end{array}$ & $\begin{array}{ll}> & \text { LUMO } \\
> & \text { LUMO+1 }\end{array}$ & $3.92,317$ & 0.00 \\
\hline $\begin{array}{c}\text { Excited } \\
\text { state } 4\end{array}$ & $\begin{array}{l}\text { HOMO-6 } \\
\text { HOMO-5 } \\
\text { HOMO-5 } \\
\text { HOMO-3 }\end{array}$ & $\begin{array}{cc}> & \text { LUMO } \\
> & \text { LUMO } \\
> & \text { LUMO+1 } \\
> & \text { LUMO }\end{array}$ & $4.03,307$ & 0.00 \\
\hline $\begin{array}{l}\text { Excited } \\
\text { state } 5\end{array}$ & $\begin{array}{l}\text { HOMO-6 } \\
\text { HOMO-5 } \\
\text { HOMO-5 }\end{array}$ & $\begin{array}{ll}> & \text { LUMO } \\
> & \text { LUMO } \\
> & \text { LUMO+1 }\end{array}$ & $4.07,305$ & 0.01 \\
\hline
\end{tabular}

Table 4. Excited states and oscillator strengths of $7 \mathrm{PyBe}$ calculated using the B3LYP/6-311++G(d,p) basis set.

\begin{tabular}{|c|c|c|c|c|}
\hline & \multicolumn{2}{|c|}{ Excited state } & $\Delta E / \mathrm{eV}, \mathrm{nm}$ & $f$ \\
\hline $\begin{array}{c}\text { Excited } \\
\text { state } 1\end{array}$ & $\begin{array}{c}\text { HOMO-1 } \\
\text { HOMO }\end{array}$ & $\begin{array}{ll}> & \text { LUMO } \\
> & \text { LUMO+1 }\end{array}$ & $3.53,351$ & 0.03 \\
\hline $\begin{array}{l}\text { Excited } \\
\text { state } 2\end{array}$ & $\begin{array}{c}\text { HOMO-1 } \\
\text { HOMO } \\
\text { HOMO }\end{array}$ & $\begin{array}{l}>\text { LUMO+1 } \\
>\quad \text { LUMO } \\
>\text { LUMO+2 }\end{array}$ & $3.72,334$ & 1.16 \\
\hline $\begin{array}{l}\text { Excited } \\
\text { state } 3\end{array}$ & $\begin{array}{c}\text { HOMO-1 } \\
\text { HOMO-1 } \\
\text { HOMO }\end{array}$ & $\begin{array}{ll}> & \text { LUMO } \\
> & \text { LUMO+2 } \\
> & \text { LUMO+1 }\end{array}$ & $3.73,332$ & 1.01 \\
\hline $\begin{array}{l}\text { Excited } \\
\text { state } 4\end{array}$ & $\begin{array}{c}\text { HOMO-1 } \\
\text { HOMO-1 } \\
\text { HOMO } \\
\text { HOMO }\end{array}$ & $\begin{array}{l}>\text { LUMO+1 } \\
>\text { LUMO+2 } \\
>\quad \text { LUMO } \\
>\text { LUMO+2 }\end{array}$ & $3.87,320$ & 0.02 \\
\hline $\begin{array}{l}\text { Excited } \\
\text { state } 5\end{array}$ & $\begin{array}{c}\text { HOMO-1 } \\
\text { HOMO-1 } \\
\text { HOMO } \\
\text { HOMO }\end{array}$ & $\begin{array}{lc}> & \text { LUMO } \\
> & \text { LUMO+2 } \\
> & \text { LUMO } \\
> & \text { LUMO+2 }\end{array}$ & $3.93,316$ & 0.11 \\
\hline
\end{tabular}




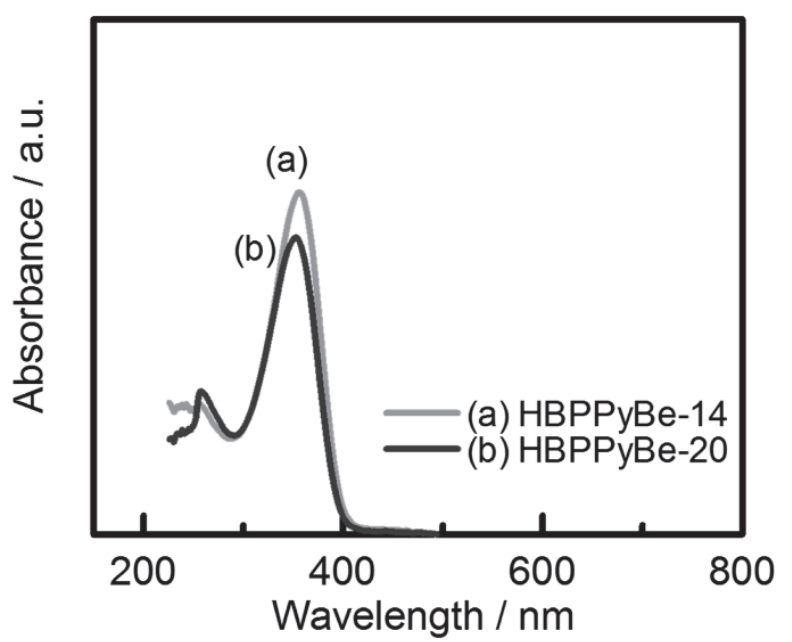

Fig. 5. Absorption spectra of HBPPyBe in formic acid.

The actual band structures of the synthesized polymers were then determined by UV-Vis absorption spectroscopy (Fig. 5) and CV (Fig. 6), and the results are summarized in Table 5. For comparison, the results for HBPPy and LPPy reported in our previous study [41] are also given in Table 5. As indicated in Fig. 5, HBPPyBe-14 and HBPPyBe-20 gave similar absorption peaks at wavelengths $<400 \mathrm{~nm}$. The onset wavelengths ( $\left.\lambda_{\text {onset }}\right)$ of these polymers were also similar to each other and to those of HBPPy and LPPy. In contrast, the maximum adsorption wavelength $\left(\lambda_{\max }\right)$ decreased slightly as the number of branching units increased in both HBPPy and HBPPyBe. In addition, the LUMO levels of HBPPyBe-14 and HBPPyBe20 were determined to be 2.67 and $2.62 \mathrm{eV}$, respectively, by cyclic voltammetry, and these values were similar to those of LPPy and HBPPy. The calculated HOMO levels of this series of polymers were also similar. Furthermore, the observed trends for the UV-Vis and CV spectra of HBPPyBe correspond to the values predicted by the DFT calculations and to the results obtained for HBPPy [41].

The kinetic effect of the branching unit on the electrochemical doping of the synthesized polymers was also examined based on the $\mathrm{CV}$ results shown in Fig. 6. All samples showed a redox couple between -2.4 and $-2.0 \mathrm{~V}$, and the reduction peak shifted slightly to more positive values as the number of branching units increased. As discussed in our previous study [41], the n-type doping of this experiment should be accompanied by diffusion of the dopant, i.e., tetrabutylammonium cations, and its diffusion within the polymer matrix should be enhanced by the hyperbranched structure due to its larger free volume [16]. To further clarify differences in the doping behavior, $\mathrm{CV}$ measurements were conducted for HBPPyBe- 20 on transparent ITO. Thus, Fig. 7 shows the change in color of the polymer films on the ITO electrodes before and after the application of a cathodic potential. More specifically, the observed color change across the entire area of the HBPPyBe-20containing ITO electrode upon n-doping can be explained considering the results for HBPPy [41]. More specifically, if the polymer matrix is packed too tightly to allow dopant diffusion, which is likely in the case of LPPy, the doping reaction can proceed on the three-phase boundary between the polymer, ITO, and the electrolyte. In contrast, the hyperbranched structure of HBPPyBe promotes diffusion of the dopant due to its large free volume, and the entire electrode area undergoes a color change due to doping. It could therefore be concluded that the advantageous properties of hyperbranched structures in the context of electrochemical doping are retained even when $\mathrm{PyBr}_{3}$ is replaced with $\mathrm{BeBr}_{3}$.

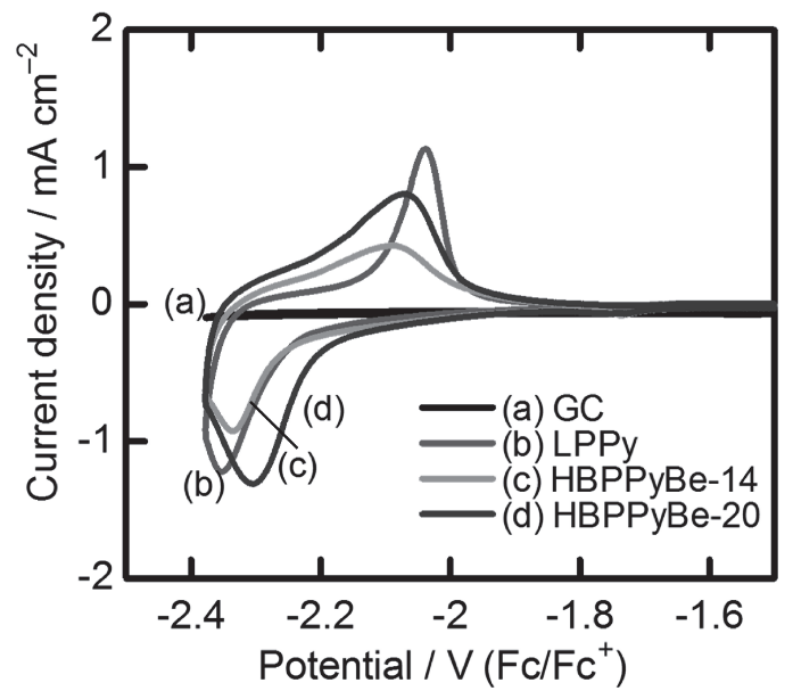

Fig. 6. Cyclic voltammograms measured at room temperature for LPPy and HBPPyBe on GC electrodes (electrolyte: acetonitrile containing $0.1 \mathrm{M}$ tetrabutylammonium tetrafluoroborate; scan rate:

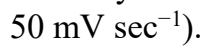

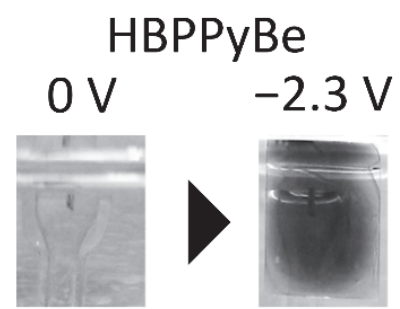

Fig. 7. Changes in the HBPPyBe-20 film color after doping. 
Table 5. Summary of the UV-Vis spectroscopy and CV results for the various polymers.

\begin{tabular}{|c|c|c|c|c|c|c|}
\hline & \multicolumn{2}{|c|}{ Absorption } & \multicolumn{2}{|c|}{$\mathrm{CV}$} & \multirow{2}{*}{$\begin{array}{c}\text { LUMO }^{\mathrm{a}} \\
\mathrm{eV} \\
\end{array}$} & \multirow{2}{*}{$\begin{array}{c}\mathrm{HOMO} \\
\mathrm{eV} \\
\end{array}$} \\
\hline & $\begin{array}{c}\lambda{ }_{\text {max }} \\
\mathrm{nm}\end{array}$ & $\begin{array}{c}\lambda_{\text {onset }} \\
\mathrm{nm}, \mathrm{eV}\end{array}$ & $\begin{array}{c}\text { Red }_{\text {onset }} \\
\mathrm{V}\end{array}$ & $\begin{array}{c}\mathrm{ReOx}_{\text {onset }} \\
\mathrm{V} \\
\end{array}$ & & \\
\hline НВРРуВе-14 & 356 & $411,3.01$ & -2.26 & -2.13 & -2.67 & -5.68 \\
\hline НВРРyВe-20 & 353 & $410,3.02$ & -2.18 & -2.17 & -2.62 & -5.64 \\
\hline НВРРу-14 [41] & 367 & $411,3.01$ & -2.23 & -2.11 & -2.69 & -5.70 \\
\hline НВРРу-20 [41] & 357 & $409,3.03$ & -2.08 & -2.14 & -2.66 & -5.69 \\
\hline HBPРy-33 [41] & 261,343 & $409,3.03$ & -2.09 & -2.14 & -2.66 & -5.69 \\
\hline LPPy [41] & 367 & $410,3.02$ & -2.22 & -2.14 & -2.66 & -5.68 \\
\hline
\end{tabular}

${ }^{a}$ The LUMO levels of the polymers were calculated from $\mathrm{ReOx}_{\text {onset. }}$.

${ }^{\mathrm{b}}$ The HOMO levels of the polymers were calculated from LUMO and $\lambda_{\text {onset. }}$.

\section{Conclusion}

Hyperbranched polypyridinebenzene was synthesized successfully by the copolymerization of 1,3,5-tribromobenzene and 2,5-dibromopyridine via chain-growth condensation polymerization. This is a facile approach for the synthesis of n-type $\pi$-conjugated hyperbranched polymers in terms of the availability of the branching unit, 1,3,5tribromobenzene. Compared to the hyperbranched polymer prepared from 2,4,6-tribromopyridine, the synthetic route to such polymers is therefore simplified without affecting the properties of the resulting hyperbranched polymers. Further studies will focus on expanding the variety of n-type $\pi$ conjugated hyperbranched polymers that can be prepared by this method through optimization of the chemical structures of the linear and branching units.

\section{Acknowledgements}

The numerical calculations were carried out using the TSUBAME2.5 supercomputer at the Tokyo Institute of Technology. The authors thank Prof Shinji Ando and Prof Takehiko Mori (Tokyo Institute of Technology) for their valuable discussions.

\section{References}

1. J. R. Pouliot, F. Grenier, J. T. Blaskovits, S. Beaupré, and M. Leclerc, Chem. Rev., 116 (2016) 14225.

2. M. Hösel, H. F. Dam, and F. C. Krebs, Energy Technol., 3 (2015) 293.

3. B. C. Thompson and J. M. J. Fréchet, Angew. Chem. Int. Ed., 47 (2008) 58.

4. S. Gauthier, B. Reisberg, M. Zaudig, R. C. Petersen, K. Ritchie, K. Broich, S. Belleville, H. Brodaty, D. Bennett, H. Chertkow, J. L. Cummings, M. de Leon, H. Feldman, M. Ganguli,
H. Hampel, P. Scheltens, M. C. Tierney, P. Whitehouse, and B. Winblad, Nature, 414 (2001) 338.

5. Y. Motoyama, M. Takasaki, S. H. Yoon, I. Mochida, and H. Nagashima, Org. Lett., 11 (2009) 5042.

6. R. H. Friend, R. W. Gymer, A. B. Holmes, J. H. Burroughes, R. N. Marks, C. Taliani, D. D. C. Bradley, D. A. Dos Santos, J. L. Brédas, M. Lögdlund, and W. R. Salaneck, Nature, 397 (1999) 121.

7. H. Bronstein, Z. Chen, R. S. Ashraf, W. Zhang, J. Du, J. R. Durrant, P. Shakya Tuladhar, K. Song, S. E. Watkins, Y. Geerts, M. M. Wienk, R. A. J. Janssen, T. Anthopoulos, H. Sirringhaus, M. Heeney, and I. McCulloch, J. Am. Chem. Soc., 133 (2011) 3272.

8. Y.-H. Chou, H.-C. Chang, C.-L. Liu, and W.-C. Chen, Polym. Chem., 6 (2015) 341.

9. F. Feng, L. Liu, Q. Yang, and S. Wang, Macromol. Rapid Commun., 31 (2010) 1405.

10. Y. Li, Acc. Chem. Res., 45 (2012) 723.

11. K. Okamoto, J. B. Housekeeper, F. E. Michael, and C. K. Luscombe, Polym. Chem., 4 (2013) 3499.

12. M. Yuan, K. Okamoto, H. A. Bronstein, and C. K. Luscombe, ACS Macro Lett., 1 (2012) 392.

13. H. Sirringhaus, P. J. Brown, R. H. Friend, M. M. Nielsen, K. Bechgaard, B. M. W. LangeveldVoss, A. J. H. Spiering, R. A. J. Janssen, E. W. Meijer, P. Herwig, and D. M. De Leeuw, Nature, 401 (1999) 685.

14. T. Yokozawa and A. Yokoyama, Chem. Rev., 109 (2009) 5595.

15. C. Gao and D. Yan, Prog. Polym. Sci., 29 (2004) 183.

16. M. Jikei and M. Kakimoto, Prog. Polym. Sci., 
26 (2001) 1233.

17. W. Wu, R. Tang, Q. Li, and Z. Li, Chem. Soc. Rev., 44 (2015) 3997.

18. M. Jikei, S. H. Chon, M. Kakimoto, S. Kawauchi, T. Imase, and J. Watanebe, Macromolecules, 32 (1999) 2061.

19. G. Yang, M. Jikei, and M. Kakimoto, Macromolecules, 31 (1998) 5964.

20. K. Yamanaka, M. Jikei, and M. Kakimoto, Macromolecules, 33 (2000) 6937.

21. K. Yamanaka, M. Jikei, and M. Kakimoto, Macromolecules, 33 (2000) 1111.

22. S. V. Vyver, J. Thomas, J. Geboers, S. Keyzer, M. Smet, W. Dehaen, P. A. Jacobs, and B. F. Sels, Energy Environ. Sci., 4 (2011) 3601.

23. M. Kakimoto, S. J. Grunzinger, and T. Hayakawa, Polym. J., 42 (2010) 697.

24. K. Matsumoto and M. Ueda, Chem. Lett., 35 (2006) 1196.

25. C. F. Shu and C. M. Leu, Macromolecules, 32 (1999) 100.

26. C. J. Hawker and F. Chu, Macromolecules, 29 (1996) 4370.

27. Y. Shi, Y. Nabae, T. Hayakawa, H. Kobayashi, M. Yabushita, A. Fukuoka, and M. Kakimoto, Polym. J., 46 (2014) 722.

28. Y. Shi, Y. Nabae, T. Hayakawa, and M. Kakimoto, RSC Adv., 5 (2015) 1923.

29. S. J. Grunzinger, M. Watanabe, K. Fukagawa, R. Kikuchi, Y. Tominaga, T. Hayakawa, and M. Kakimoto, J. Power Sources, 175 (2008) 120.

30. Y. Nabae, M. Tomita, T. Taniguchi, J. Liang, K. Yamamoto, T. Hayakawa, and M. Kakimoto, Polymer, 137 (2018) 324.

31. Y. Nabae, M. Mikuni, T. Hayakawa, and M. Kakimoto, J. Photopolym. Sci. Technol., 27 (2014) 139.

32. Y. Shi, Y. Nabae, T. Hayakawa, and M. Kakimoto, J. Photopolym. Sci. Technol., 28 (2015) 187.

33. C. Pitois, D. Wiesmann, M. Lindgren, and A. Hult, Adv. Mater., 13 (2001) 1483.
34. J. Li, X. Wang, G. Chen, D. Li, Y. Zhou, X. Yang, and J. Wang, Appl. Catal. B Environ., 176 (2015) 718.

35. Z. Wang, H. Liu, H. Cui, M. Zhang, and Z. Zhang, Ind. Eng. Chem. Res., 54 (2015) 7219.

36. Y. Nabae, J. Liang, X. Huang, T. Hayakawa, and M. Kakimoto, Green Chem., 16 (2014) 3596.

37. Y. H. Kim and O. W. Webster, Macromolecules, 25 (1992) 5561.

38. A. Adronov and J. M. J. Fréchet, Chem. Comm., 18 (2000) 1701.

39. M. H. Xu and L. Pu, Tetrahedron Lett., 43 (2002) 6347.

40. T. V. Richter, S. Link, R. Hanselmann, and S. Ludwigs, Macromol. Rapid Commun., 30 (2009) 1323.

41. T. Koga, Y. Nabae, A. Funakawa, T. Hayakawa, and M. Kakimoto, Macromol. Chem. Phys., 218 (2017) 1700391.

42. M. J. Frisch, G. W. Trucks, H. B. Schlegel, G. E. Scuseria, M. A. Robb, J. R. Cheeseman, G. Scalmani, V. Barone, B. Mennucci, G. A. Petersson, H. Nakatsuji, M. Caricato, X. Li, H. P. Hratchian, A. F. Izmaylov, J. Bloino, G. Zheng, J. L. Sonnenberg, M. Hada, M. Ehara, K. Toyota, R. Fukuda, J. Hasegawa, M. Ishida, T. Nakajima, Y. Honda, O. Kitao, H. Nakai, T. Vreven, J. A. Montgomery, J. E. Peralta, F. Ogliaro, M. Bearpark, J. J. Heyd, E. Brothers, K. N. Kudin, V. N. Staroverov, R. Kobayashi, J. Normand, K. Raghavachari, A. Rendell, J. C. Burant, S. S. Iyengar, J. Tomasi, M. Cossi, N. Rega, J. M. Millam, M. Klene, J. E. Knox, J. B. Cross, V. Bakken, C. Adamo, J. Jaramillo, R. Gomperts, R. E. Stratmann, O. Yazyev, A. J. Austin, R. Cammi, C. Pomelli, J. W. Ochterski, R. L. Martin, K. Morokuma, V. G. Zakrzewski, G. A. Voth, P. Salvador, J. J. Dannenberg, S. Dapprich, A. D. Daniels, J. B. Farkas, Foresman, J. V. Ortiz, J. Cioslowski, and D. J. Fox, Gaussian 09, Revision E.01, Gaussian, Inc., Wallingford CT, (2009). 